\title{
Extensive Studies on Biomorphic SiC Ceramics Properties for Medical Applications
}

\author{
P. González ${ }^{1}$, J.P. Borrajo ${ }^{1}$, J. Serra' ${ }^{1}$, S. Liste ${ }^{1}$, S. Chiussi ${ }^{1}$, B. León ${ }^{1}$, K. \\ Semmelmann ${ }^{2}$, A. de Carlos ${ }^{2}$, F.M. Varela-Feria ${ }^{3}$, J. Martínez-Fernández ${ }^{3}$, \\ A.R. de Arellano-López ${ }^{3}$ \\ ${ }^{1}$ Universidad de Vigo, Dpto. Física Aplicada, Lagoas-Marcosende, 36200 Vigo, Spain, \\ pglez@uvigo.es \\ ${ }^{2}$ Universidad de Vigo, Dpto. Bioquímica, Genética e Inmunología, Lagoas-Marcosende, 36200 \\ Vigo, Spain \\ ${ }^{3}$ Universidad de Sevilla, Dpto. Física de la Materia Condensada, Apdo. 1065, 41080 Sevilla, Spain
}

Keywords: silicon carbide, bioceramics, biomaterials, EDS, XPS, XRF

\begin{abstract}
Biomorphic silicon carbide ceramics are light, tough and high-strength materials with interesting biomedical applications. The fabrication method of the biomorphic $\mathrm{SiC}$ is based in the infiltration of molten-Si in carbon preforms with open porosity. The final product is a biostructure formed by a tangle of $\mathrm{SiC}$ fibers. This innovative process allows the fabrication of complex shapes and the tailoring of $\mathrm{SiC}$ ceramics with optimised properties and controllable microstructures that will match the biomechanical requirements of the natural host tissue. An interdisciplinary approach of the biomorphic SiC fabricated from beech, sapelly and eucalyptus is presented. Their mechanical properties, microstructure and chemical composition were evaluated. The biocompatible behaviour of these materials has been tested in vitro.
\end{abstract}

\section{Introduction}

In the last decades many materials have been developed and improved for medical applications, such as metals, ceramics, glasses, polymers and composites. In particular, there has been a recent interest in the research and development of biomaterials from natural biological structures with an open porosity. The challenge of the implant technology is to get lighter materials, with enhanced mechanical properties, wear resistance and with better biological response.

Biomorphic silicon carbide ceramics are very promising as a natural base material for dental and orthopaedic implants due to their unique mechanical and microstructural properties. This innovative material is produced by molten-Si infiltration of carbon templates obtained by controlled pyrolysis of wood [1]. This innovation introduces two beneficial factors: first, the versatility for the fabrication of complex shapes, because it will only require the shaping of the wood template, and secondly, the high strength and toughness associated with the fibrous nature of the wood. The biodiversity of the natural grown wood structures offers a large variety of templates with different porosity and morphologies [2]. The $\mathrm{SiC}$ ceramics retain the microstructural details of the biostructure derived carbon preforms and it allows the tailoring of a wide range of SiC ceramics with optimised microstructure and properties close to those of the tissue to be repaired. The final product is a light, tough and high-strength material, with controllable microstructure, that mimics the starting wood fibrous structure that has been perfected by natural evolution.

Presented in this work is an extensive study on the physico-chemical and mechanical properties, as well as the biocompatible behaviour of biomorphic SiC ceramics obtained from three selected woods. 


\section{Materials and methods}

Biomorphic $\mathrm{SiC}$ has been obtained from beech, sapelly and eucalyptus woods. The samples are pyrolyzed in an argon atmosphere at $1000^{\circ} \mathrm{C}$ with well-controlled heating and cooling ramps. The porous carbon preforms are then infiltrated with liquid silicon in vacuum. A subsequent spontaneous reaction forms $\mathrm{SiC}$ [1].

Room temperature crushing strength experiments were performed using a universal mechanical testing machine. Compressive rates were $2 \times 10^{-5} \mathrm{~s}^{-1}$ on $5 \times 2 \times 2 \mathrm{~mm}^{3}$ samples tested along their longer axis. Specimens were cut for testing both parallel (axial) and perpendicular (radial) to the direction of growth of the wood.

In order to assess possible adverse physiological effects in the body, in vitro tests were carried out by soaking the $\mathrm{SiC}$ ceramics in $1,5 \mathrm{ml}$ of Simulated Body Fluid (SBF) [3] at $37^{\circ} \mathrm{C}$ for 1 week. Chemical analyses of the SiC ceramics and the fluids for the identification of the composition and the trace element content by Energy Dispersive X-Ray Spectroscopy (EDS), X-Ray Fluorescence Spectrometry (XRF), X-Ray Photoelectron Spectroscopy (XPS) and Inductively Coupled Plasma Mass Spectrometry (ICP-MS) were performed. Cytotoxicity was assessed performing a solvent extraction test according to ISO 10993 standards, using PVC and Thermanox as positive and negative controls respectively. MG-63 osteoblast-like cells were grown to confluent layers in 96well tissue culture plates and tested against different concentrations of the extracts for 24 hours. The cell viability was assessed by determining the reduction of MTT measuring the absorbance in each of the wells.

\section{Results and discussion}

Figure 1 shows the microstructure of the three Bio-SiC materials used in this study. Different porous size and porosity grade can be observed. The biomorphic microstructure resembles the cellular microstructure of bone, and this type of large porosity may contribute to the vasculature of the repaired tissue around the implant, providing a route for migration of osteogenic cells and, consequently, new bone formation within the implant.
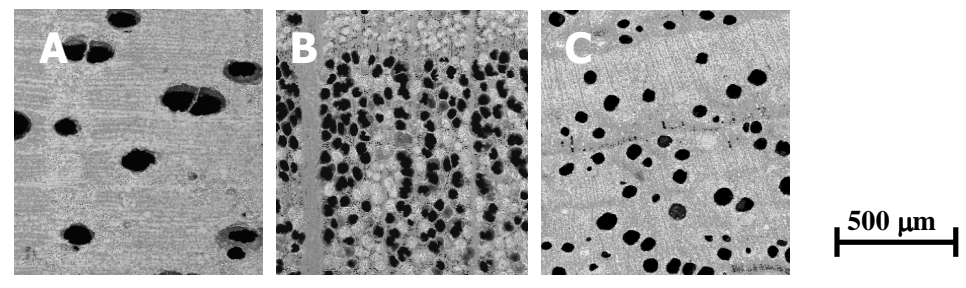

Fig. 1. SEM cross-sections of Bio-SiC materials from (A) sapelly, (B) beech and (C) eucalyptus wood.

Table 1 presents the densities of the woods, the carbon preforms and the density of the SiC skeleton, which controls the mechanical properties of the material. Error bars are assessed to be less than $5 \%$.

Depending on the amount of remaining Si filling the porosity of Bio-SiC, the bulk density of the material can vary. When all porosity is filled with $\mathrm{Si}$ these three Bio-SiC materials reach a density of approximately $2.0 \mathrm{~g} . \mathrm{cm}^{-3}$. Recent developments have shown that unreacted $\mathrm{Si}$ can be removed by appropriate chemical treatment. If all porosity is empty, then the density is that

\begin{tabular}{|c|c|c|c|}
\hline \multirow{3}{*}{ Table 1. Densities of Bio-SiC } \\
\cline { 2 - 4 } \multicolumn{1}{c|}{} & \multicolumn{3}{|c|}{ Density $\left(\mathrm{g} . \mathrm{cm}^{-3}\right)$} \\
\cline { 2 - 4 } & Wood & Carbon & SiC \\
\hline Sapelly & 0.61 & 0.36 & 1.15 \\
\hline Beech & 0.70 & 0.48 & 1.42 \\
\hline Eucalyptus & 0.79 & 0.58 & 1.57 \\
\hline
\end{tabular}


shown in Table 1 as SiC.

As demonstrated, an important advantage of this process is the possibility to tune the density of this material in a wide range $\left(1,15-2 \mathrm{~g} \cdot \mathrm{cm}^{-3}\right)$. Biomorphic $\mathrm{SiC}$ is defined as a light material, because its density is very low in comparison with the literature values of the theoretical density of $\mathrm{SiC}\left(3.21 \mathrm{~g} . \mathrm{cm}^{-3}\right)$ and both medical-grade Ti $\left(4,51 \mathrm{~g} . \mathrm{cm}^{-3}\right)$ and Ti-alloy $\left(4,42 \mathrm{~g} . \mathrm{cm}^{-3}\right)$.

The room-temperature crushing strengths of the three types of Bio-SiC, in axial and perpendicular direction are included in Table 2. For comparison purposes, literature crushing strengths of cortical bone, and both medical-grade $\mathrm{Ti}$ and Ti-alloy are shown.

As observed, the microstructure and mechanical properties of the material can be tailored by an appropriate wood precursor selection. From the material science point of view, the bulk properties of this material will match the biomechanical requirements of a particular type of natural host tissue that should be repaired.

Concerning the chemical composition of these ceramics, EDS analyses show that this biomorphic material is a composite of a $\mathrm{SiC}$ skeleton with small amounts of unreacted $\mathrm{Si}$ and C. Recent studies conclude that the residual silicon does not present adverse physiological effects in the body; $\mathrm{Si}$ is safely excreted through the urine and no accumulation was found distributed in the major organs [4]. Table 3 shows the XRF and XPS analyses of the three $\mathrm{SiC}$ types. The elements identified by both techniques are marked in grey. The measurements reveal the majority presence of $\mathrm{Si}$ and C. Small amounts of $\mathrm{Ca}$ were found in all samples and, in some cases, $\mathrm{Al}, \mathrm{Cu}$ and $\mathrm{Na}$. Other trace elements were also identified in very low concentrations.

The

biocompatible behaviour of this material has been tested by soaking the $\mathrm{SiC}$ ceramics in Simulated Body Fluid. Table 4 shows the ICPMS analyses of the SBF fluids after one-week immersion of the Bio-SiC materials. The SBF element concentrations used as reference values are also shown. Only weak signals

\begin{tabular}{|c|c|c|}
\hline \multicolumn{2}{|c|}{ Table 2. Crushing Strength results } \\
\cline { 2 - 3 } \multicolumn{1}{c|}{ Strength (MPa) } \\
\cline { 2 - 3 } & Axial & Radial \\
\hline Bone [6] & 195 & 135 \\
\hline Ti [7] & 310 & -- \\
\hline Ti-6Al-4V [7] & 880 & -- \\
\hline Sapelly & $1070 \pm 200$ & $105 \pm 20$ \\
\hline Beech & $1160 \pm 300$ & $530 \pm 100$ \\
\hline Eucalyptus & $1175 \pm 400$ & $165 \pm 60$ \\
\hline
\end{tabular}

Table 3. Chemical composition of Bio-SiC

\begin{tabular}{|c|cc|cc|cc|}
\hline \multirow{2}{*}{ Element } & \multicolumn{6}{|c|}{ Bio-SiC type } \\
\cline { 2 - 6 } & \multicolumn{2}{|c|}{ Beech } & \multicolumn{2}{|c|}{ Sapelly } & \multicolumn{2}{|c|}{ Eucalyptus } \\
\cline { 2 - 6 } & XRF & XPS & XRF & XPS & XRF & XPS \\
\hline $\mathrm{Al}$ & $\mathrm{X}$ & & $\mathrm{X}$ & $\mathrm{X}$ & $\mathrm{X}$ & $\mathrm{X}$ \\
$\mathrm{B}$ & & & & $\mathrm{X}$ & & $\mathrm{X}$ \\
$\mathrm{C}$ & $\mathrm{X}$ & $\mathrm{X}$ & $\mathrm{X}$ & $\mathrm{X}$ & $\mathrm{X}$ & $\mathrm{X}$ \\
$\mathrm{Ca}$ & $\mathrm{X}$ & $\mathrm{X}$ & $\mathrm{X}$ & $\mathrm{X}$ & $\mathrm{X}$ & $\mathrm{X}$ \\
$\mathrm{Cr}$ & & & & & $\mathrm{X}$ & \\
$\mathrm{Cu}$ & $\mathrm{X}$ & & $\mathrm{X}$ & & $\mathrm{X}$ & $\mathrm{X}$ \\
$\mathrm{Fe}$ & $\mathrm{X}$ & & $\mathrm{X}$ & & $\mathrm{X}$ & \\
$\mathrm{K}$ & $\mathrm{X}$ & & $\mathrm{X}$ & & $\mathrm{X}$ & \\
$\mathrm{La}$ & & & & & $\mathrm{X}$ & \\
$\mathrm{Mn}$ & & & & & $\mathrm{X}$ & \\
$\mathrm{N}$ & & $\mathrm{X}$ & & $\mathrm{X}$ & & $\mathrm{X}$ \\
$\mathrm{Na}$ & $\mathrm{X}$ & & $\mathrm{X}$ & & $\mathrm{X}$ & $\mathrm{X}$ \\
$\mathrm{O}$ & & $\mathrm{X}$ & & $\mathrm{X}$ & & $\mathrm{X}$ \\
$\mathrm{P}$ & $\mathrm{X}$ & & $\mathrm{X}$ & & $\mathrm{X}$ & \\
$\mathrm{S}$ & $\mathrm{X}$ & & $\mathrm{X}$ & & $\mathrm{X}$ & \\
$\mathrm{Si}$ & $\mathrm{X}$ & $\mathrm{X}$ & $\mathrm{X}$ & $\mathrm{X}$ & $\mathrm{X}$ & $\mathrm{X}$ \\
$\mathrm{Ti}$ & $\mathrm{X}$ & & $\mathrm{X}$ & & $\mathrm{X}$ & \\
$\mathrm{Zn}$ & & & & & $\mathrm{X}$ & \\
\hline
\end{tabular}

\begin{tabular}{|c|c|ccc|}
\hline \multicolumn{6}{|c|}{ Table 4. Release test of Bio-SiC (mg/l) } \\
\begin{tabular}{|c|c|ccc|}
\hline Element & SBF & Beech & Sapelly & Eucalyptus \\
\hline $\mathrm{Al}$ & 0,014 & 0,007 & 0,005 & 0,004 \\
$\mathrm{Ca}$ & 93 & 104 & 97,8 & 86,4 \\
$\mathrm{Cu}$ & 0,01 & 0,375 & 0,097 & 0,166 \\
$\mathrm{Fe}$ & $<0,005$ & $<0,005$ & $<0,005$ & $<0,005$ \\
$\mathrm{P}$ & 37,1 & 32,4 & 33,8 & 32,3 \\
$\mathrm{~S}$ & 4,62 & 6,33 & 5,3 & 4,5 \\
$\mathrm{Si}$ & 0,369 & 5,76 & 4,69 & 0,829 \\
$\mathrm{Ti}$ & $<0,005$ & $<0,005$ & $<0,005$ & $<0,005$ \\
\hline
\end{tabular}
\end{tabular}


related to the release of $\mathrm{Si}$ and $\mathrm{Cu}$ until reaching concentration values in the order of ppm were observed. Most of the elements remain unchanged within experimental error. Therefore, it can be concluded that no important dissolution rate of these materials is observed and no adverse physiological effects in the body are expected.

Figure 2 summarises the result of a representative solvent extraction test. Cells incubated with the biomorphic $\mathrm{SiC}$ extracts at different concentrations showed viability rates similar to those obtained for the negative control. Only a slight decrease in cell activity could be observed when the eucalyptus and sapelly extract concentrations were $100 \%$.

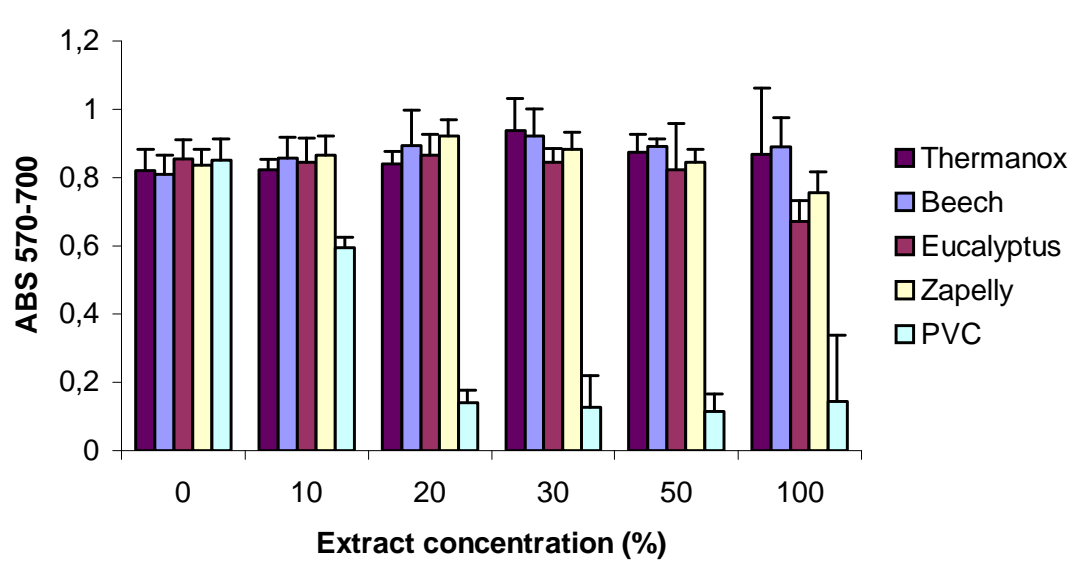

Fig. 2. Solvent extraction test using PVC and Thermanox as positive and negative controls, respectively.

This interdisciplinary study demonstrates that biomorphic SiC ceramics are promising materials for medical applications. Moreover, these ceramics can be successfully coated with a bioactive glass layer [5], which will improve the biological response of this new product.

\section{Conclusions}

Biomorphic SiC ceramics appear as an interesting alternative to $\mathrm{Ti}$ implants, by showing higher biomechanical requirements and lower density. The in vitro biocompatible behaviour of the biomorphic SiC obtained from three selected woods is demonstrated.

\section{Acknowledgements}

The authors wish to thank Ángeles Fernández for her collaboration during the experimental work. This work was supported by Xunta de Galicia (PGIDT02PXIC30302PN), Universidad de Vigo (64502I908 and 6452I106) and Ministerio de Ciencia y Tecnología (MAT2001-3434).

\section{References}

[1] M. Singh: Ceram. Sci. Eng. Proc. Vol. 21 (2000), p. 39.

[2] F.M. Varela-Feria, J. Martínez-Fernández, A.R. de Arellano López and M. Singh: Ceramics Engineering Science Proceedings Vol. 23 (2002), p. 681.

[3] T. Kokubo, M. Tanahashi, T. Yao, M. Minoda, T. Miyamoto, T. Nakamura and T. Yamamuro: Bioceramics Vol. 6 (1993), p. 327.

[4] W. Lai, J. Garino and P. Ducheyne: Biomaterials Vol. 23 (2002), p. 213.

[5] P. González, J. Serra, S. Liste, S. Chiussi, B. Léon, M. Pérez-Amor, J. Martínez-Fernández, A. R. de Arellano-López and F.M. Varela-Feria: Biomaterials (2003) in press.

[6] L.J. Gibson, M.J. Ashby: Cellular Solids (Pergamon Press, Oxford 1988)

[7] P.L. Mangonon: The Principles of Materials Selection for Engineering Design (Prentice-Hall, First Edition, Upper Saddle River, New Jersey 1999) 
Bioceramics 16

10.4028/www.scientific.net/KEM.254-256

Extensive Studies on Biomorphic SiC Ceramics Properties for Medical Applications 10.4028/www.scientific.net/KEM.254-256.1029 